
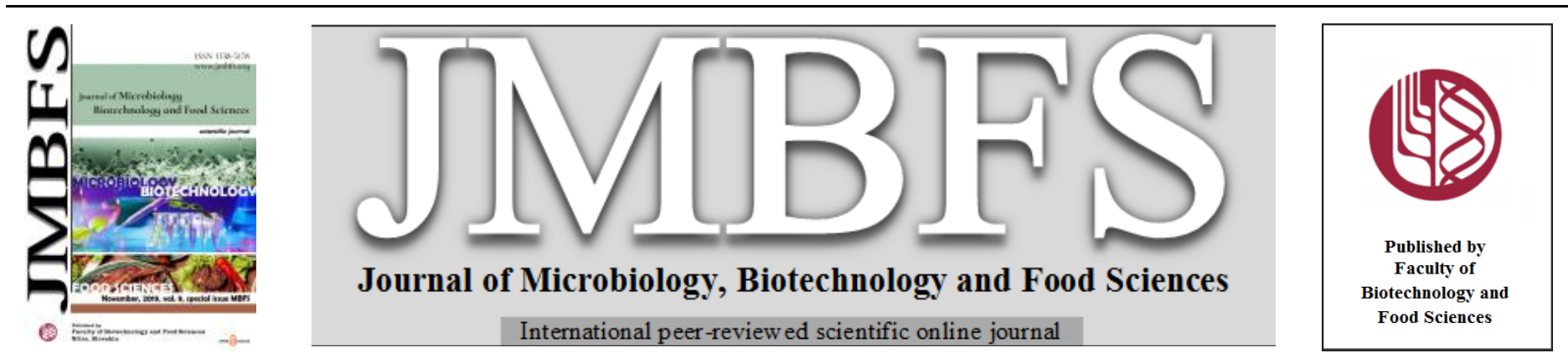

\title{
BIOLOGICAL ACTIVITY OF ESSENTIAL OILS AGAINST STAPHYLOCOCCUS SPP. ISOLATED FROM HUMAN SEMEN
}

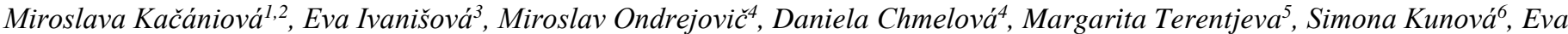 \\ Tvrdá
}

Address(es):

${ }^{1}$ Slovak University of Agriculture in Nitra, Faculty of Horticulture and Landscape Engineering, Department of Fruit Sciences, Viticulture and Enology, Trieda Andreja Hlinku 2, 94976 Nitra, Slovakia, phone number: +421 376414985

${ }^{2}$ University of Rzeszow, Faculty of Biology and Agriculture, Department of Bioenergy and Food Technology, Zelwerowicza St. 4, PL-35601 Rzeszow, Poland,

${ }^{3}$ Slovak University of Agriculture, Faculty of Biotechnology and Food Sciences, Department of Technology and Quality of Plant Products, Tr. A. Hlinku 2, SK-94976

Nitra, Slovakia,

${ }^{4}$ University of Ss. Cyril and Methodius Faculty of Natural Sciences, Department of Biotechnology,, Nám. J. Herdu 2, Trnava, 917 01, Slovakia

${ }^{5}$ Latvia University of Life Sciences and Technologies, Institute of Food and Environmental Hygiene, Faculty of Veterinary Medicine, Latvia K. Helmana iela 8, LV-

3004, Jelgava, Latvia,

${ }^{6}$ Slovak University of Agriculture, Faculty of Biotechnology and Food Sciences, Department of Food Safety and Hygiene, Trieda Andreja Hlinku 2, 94976 Nitra, Slovakia, phone number: +421 376415807

${ }^{7}$ Slovak University of Agriculture, Faculty of Biotechnology and Food Science, Department of Animal Physiology, Tr. A. Hlinku 2, 94976 Nitra, Slovakia.

*Corresponding author: miroslava.kacaniova@gmail.com

doi: 10.15414/jmbfs.2019.9.special.404-408

\section{ARTICLE INFO}

Received 30. 6. 2019

Revised 23. 9. 2019

Accepted 7. 10. 2019

Published 8. 11. 2019

Regular article OPEN $\partial_{\text {ACCESS }}$

\begin{abstract}
The antimicrobial and antioxidant activities of 5 commercial plant essential oils (Citrus paradisi peel oil, Citrus reticulata peel oil, Juniperus communis fruit oil, Eucalyptus globulus leaf oil, and Cananga odorata flower) were determined. Essential oil samples were analysed by GC-FID chromatography (Agilent 6890N). Furthermore, the plant essential oils were tested using antioxidant activity and antimicrobial activity test against 19 species of Staphylococcus spp. isolated from human semen and identified with MALDI-TOF MS Biotyper. Antioxidant activities test using DPPH method revealed that Cannaga odorata had the higher antioxidant activity and the essential oil showed a positive effect. This activity is probably due the high content of benzyl benzoate and caryophyllene, which are the dominant compounds in this kind of oil. The lowest antioxidant activity was found for Juniperus communis essential oil. Antimicrobial activities showed that all tested essential oils inhibited the growth of 19 staphylococci studied. However, C. paradise, C. reticulata, J. communis and $C$. odorata had the best antimicrobial effect against $S$. hominis, whereas E. globulus essential oil has the best antimicrobial activity against $S$. aureus and S. capiti.
\end{abstract}

Keywords: antioxidant activity, antimicrobial activity, bacteria, spermatozoa, GC-FID chromatography

\section{INTRODUCTION}

Some bacteria are deleterious to the spermatozoa in a concentration-dependent manner. The most extensively studied is the effect of Escherichia coli on human spermatozoa survival. This Gram-negative bacterium reduces sperm motility through sperm adhesion and agglutination (Monga and Roberts, 1994). Staphylococcus aureus (S. aureus) is one of the most common pathogens causing both human and animal infections. Transmission of $S$. aureus to humans via contaminated food continues to be a health public concern (Qiuchun et al., 2019). Staphylococcus aureus (S. aureus) is an important zoonotic pathogen, which can infect both humans and animals. It is widely distributed in the nature and is present in air, water and feed; it also exists on the surface of the human body, in the nasal cavity, on animal fur, and in the digestive tract among other sites. S. aureus has been responsible for several infectious diseases including tissue and skin infections, pneumonia, sepsis, mastitis, arthritis, and soft tissue infections (David and Daum, 2010; Tong et al., 2015). Livestock products can act as a source of $S$. aureus zoonotic infections, and handling or consuming of contaminated food could potentially result in transmission to humans (Feingold et al., 2012; Papadopoulos et al., 2018).

Citrus essential oils (O) have been applied in many products, such as foods, beverages, cosmetics and medicines, as flavouring agents as well as for aromatherapy. They are also used for their germicidal, antioxidant and anticarcinogenic properties (Uysal et al., 2011). The active constituents of citrus Essential oils (Eos), such as limonene, $\alpha$-pinene, $\beta$-pinene and $\alpha$-terpinolene exhibit a wide spectrum of antimicrobial activity, as convinced by many studies in other plants (Cristóbal-Luna, et al., 2018Citrus fruits are a distinctive berries with the internal parts divided into segments. The number of natural species is unclear, as many of the named species are hybrids. Grapefruit (Citrus paradisi. L) belongs to the Citrus genus, a taxa of flowering plants in the family Rutaceae. The grapefruit is believed to have arisen from the pomelo or shaddock (Citrus grandis) or as a hybrid between pomelo and sweet orange. Mandarin fruits (Citrus reticulata, family Rutaceae) are one of the most abundant edible citruses in the fresh fruit markets. Mandarin peel oil is usually obtained through the coldpressing process. There are three different types of cold-pressed mandarin oil distinguished by the colour and maturity of the fruits: the so-called "green oil" is obtained from immature fruits and mainly used as fragrance, the "yellow oil" is obtained from mature fruits, being used as flavour and fragrance, while completely matured ones are used to produce the "red oil", mainly used as flavour (Reeve and Arthur, 2002). Main components of mandarin peel oil are limonene (up to 95 wt.\%) and other terpenes, like $\gamma$-terpinene. Oxygenated components (from 0.2 to $1.5 \mathrm{wt} \%$ ) like linalool, decanal and citral have the highest contribution to the aroma fraction (Lota et al., 2001). Essential oils are the odorous, volatile products of the secondary metabolism of an aromatic plant, which are often concentrated in a particular organ of the plant such as leaves, stems, bark or fruit and are stored in secretory cells, cavities, canals, epidermic cells or glandulartrichomes (Gilles et al., 2010). Juniperus (Cupressaceae) is a plant widely cultivated in the northern hemisphere. This species grows as trees or shrubs. Traditionally, Juniperus has shown several applications, mainly related to its medicinal properties and a highly specific flavour which are associated to its volatile oil components (Carpenter et al., 2014). Most of the organs of this plant contain essential oils, but it is mainly extracted from the berries, needles, branches and roots (Foudil-Cherif and Yassaa, 2012). The eucalyptus oils can 
be found in the leaves of more than 300 species of this genus and less than 20 of these have ever been exploited commercially for the production of essential oils rich in 1,8-cineole by pharmaceutical and cosmetic industries (Elaissi et al., 2011 Ylang-ylang (Cananga odorata) is one of the plants that are exploited at a large scale for its essential oil which is an important raw material for the fragrance industry. The essential oils extracted via steam distillation from the plant have been used mainly in cosmetic industry but also in food industry. Traditionally, $C$. odorata is used to treat malaria, stomach ailments, asthma, gout, and rheumatism. The essential oils or ylang-ylang oil is used in aromatherapy and is believed to be effective in treating depression, high blood pressure, and anxiety (Tan et al., 2015)

The aim of this study was to determine the chemical and biological properties of selected essential oils. From a biological point of view, we studied the antimicrobial and antioxidant activity of essential oils against staphylococci from sperm identified with MALDI-TOF MS Biotyper.

\section{MATERIAL AND METHODS}

\section{Essential oils}

Samples of commercial pure essential oils: Citrus paradisi peel oil, Citrus reticulata peel oil, Juniperus communis fruit oil, Eucalyptus globulus leaf oil, an Cananga odorata flower oil, obtained via steam distillation were purchased from Aromatika (Russia). The essential oil samples were stored in glass vials with teflon-sealed caps at laboratory temperature in the absence of light.

\section{Gas chromatography}

Essential oil samples were analysed by Agilent 6890N (Agilent Technologies, Santa Clara, CA, USA) with FID detector. System control and data analysis were processed using the Agilent ChemStation software Rev. B.04.03-SP1 (Agilent Technologies, Santa Clara, CA, USA). The chromatographic separation was performed in the DB-23 column $(0.25 \mathrm{~mm}$ i.d., $30 \mathrm{~m}$ long, $0.25 \mu \mathrm{m}$ film thickness) (Agilent Technologies), and $5 \mu$ of the sample was injected. The injector temperature was $250{ }^{\circ} \mathrm{C}$, and the FID temperature is set at $250{ }^{\circ} \mathrm{C}$. The carrier gas (nitrogen) flow was $1.1 \mathrm{ml} / \mathrm{min}$ (constant flow) with a split ratio $1: 100$ and a temperature program from $40{ }^{\circ} \mathrm{C}$ to $80{ }^{\circ} \mathrm{C}$ at $3{ }^{\circ} \mathrm{C} / \mathrm{min}$, from $80{ }^{\circ} \mathrm{C}$ to 180 ${ }^{\circ} \mathrm{C}$ at $5^{\circ} \mathrm{C} / \mathrm{min}$, and from $180^{\circ} \mathrm{C}$ to $220^{\circ} \mathrm{C}$ at $8{ }^{\circ} \mathrm{C} / \mathrm{min}$ and finally held at $220^{\circ} \mathrm{C}$ for $15 \mathrm{~min}$.

\section{Radical scavenging activity - DPPH method}

Radical scavenging activity of essential oils was measured using 2,2-diphenyl-1 picrylhydrazyl (DPPH) according to methodic by Sanchéz-Moreno et al., (1998) with slight modification. The sample $(0.1 \mathrm{ml})$ was mixed with $3.9 \mathrm{ml}$ of DPPH solution $(0.025 \mathrm{~g}$ DPPH in $100 \mathrm{ml}$ methanol). Absorbance of the reaction mixture was determined using the spectrophotometer Jenway (6405 UV/Vis, England) at $515 \mathrm{~nm}$. The scavenging activity percentage (AA\%) was determined according formula:

$\mathrm{AA} \%=\left[\left(A_{0}-A_{A T}\right) / A_{0} \times 100\right]$

where $\mathrm{A}_{0}$ is absorbance of control reaction (DPPH radical); $\mathrm{A}_{1}$ is the absorbance in presence of sample

Antimicrobial activity

\section{Microorganisms}

Nineteen different kinds of staphylococci were isolated from human semen. The semen samples were obtained from 30 healthy donors by masturbation into sterile container. Only ejaculates showing normal semen parameters were used. The samples underwent liquefaction at $37{ }^{\circ} \mathrm{C}$ for $30 \mathrm{~min}$. Experiments were performed within $1 \mathrm{~h}$ from sample collection. The samples were inoculated on Tryptone Soya agar (TSA) and Levine agar (LA). After incubation the bacteria were selected for further confirmation with MALDI-TOF MS Biotyper. Isolated staphylococci were tested for antibiotics resistance against tobramycin $10 \mathrm{msg}$. Following six human sperm isolates were tested: Staphylococcus aureus (4 isolates), S. capiti (3 isolates), S. epidermidis (4 isolates), S. haemoliticus (4 isolates), $S$. hominis (4 isolates). The bacteria species were maintained in Mueller Hinton Agar (Merck, Germany). The mother cultures of each staphylococci were set up $24 \mathrm{~h}$ before the assays in order to reach the stationary phase of growth. The tests were assessed by inoculating Petri dishes from the mother cultures with proper sterile media. The main aim was to obtain the microorganism concentration of $10^{5}$ colony forming units cfu. $\mathrm{mL}^{-1}$.

\section{Antibiotic susceptibility testing}

he antibiotic susceptibility test was performed by using Disc Diffusion Method Four different forms of sensitivity discs with $10 \mathrm{mcg}$ concentrations were used for studying the in vitro sensitivity of isolates: tobramycin.(TOB). These discs were obtained from "Oxoid". The results were interpreted according to EUCAST (2019).

\section{Disc diffusion method}

We used the agar disc diffusion method for the determination of antimicrobial activities of the essential oil. Briefly, a suspension of the tested microorganism $\left(0.1 \mathrm{~mL}\right.$ of $10^{5}$ cells per $\left.\mathrm{ml}\right)$ was spread on the solid media plates. Filter paper discs (6 mm in diameter) were impregnated with $15 \mu \mathrm{l}$ of the oil and placed on the inoculated plates. They were inoculated onto the surface of Mueller Hinton Agar (MHA, Oxoid, Basingstoke, United Kingdom). These plates, after remaining at $4{ }^{\circ} \mathrm{C}$ for 2 hours, were incubated anaerobically at $37{ }^{\circ} \mathrm{C}$ for $24 \mathrm{~h}$ The diameters of the inhibition zones were measured in millimeters. All the tests were performed in duplicate.

\section{Statistical analyses}

All measurements and analyses were carried out in triplicate. Experimental data were evaluated by basic statistical variability indicators using the Microsoft ${ }^{\mathrm{TM}}$ Excel ${ }^{\circledR}$ program. Dependency rate between the tested traits was expressed using the linear correlation analysis.

\section{RESULTS AND DISCUSSION}

Different kinds of essential oils from various plant material (Citrus paradisi, Citrus reticulata, Juniperus communis, Eucalyptus globulus, and Cananga odorata) were tested. The most intensive peak in $C$. paradisi essential oil was registered at $15.83 \mathrm{~min}$ with area percentage of $87 \%$ (Fig. 1). Okunowo et al (2013) identified 19 compounds in $C$. paradise essential oil and the most abundant compound in sample was D-limonene (75.1\%), following $\beta$-myrcene (7.3\%), $\alpha$-pinene $(2.1 \%)$, caryophyllene $(1.9 \%)$, octanal $(1.7 \%), \beta$ phellandrene $(1.2 \%)$ and decanal $(1.1 \%)$.

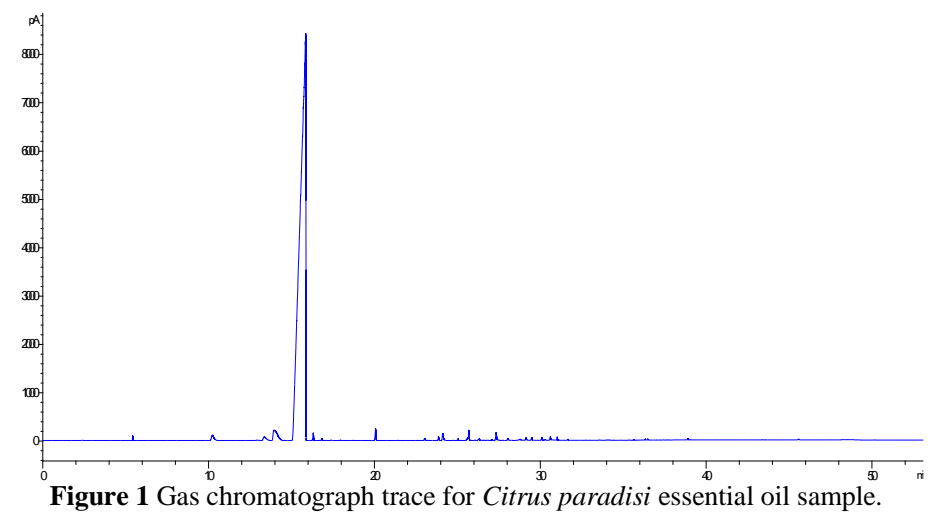

The analysis of essential oil from $C$. reticulata showed the dominant peak at $15.89 \mathrm{~min}$. (85\% of area percentage) (Fig. 2). Similar peak was observed at GC of $C$. paradisi essential oil sample (Fig. 1). Limonene (80.3\%), $\gamma$-terpinene $(4.7$ $\%)$, myrcene $(2.1 \%), \alpha$-pinene $(1.2 \%)$ and octanal $(1.0 \%)$ were identified in $C$. reticulata Blanco (Ponkan) peel oil (Sawamura et al., 2004).

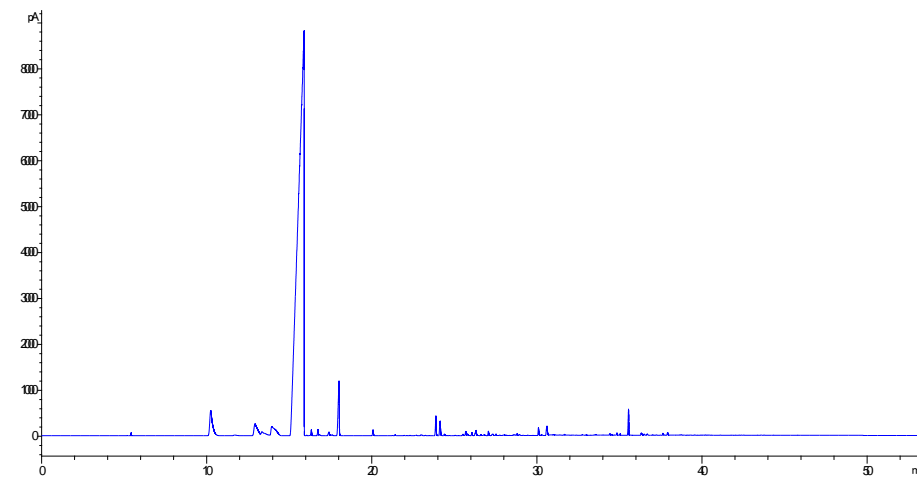

Figure 2 Gas chromatograph trace for Citrus reticulata essential oil sample.

The major peaks determined for $J$. communis essential oil sample were identified at $10.75 \mathrm{~min}(66.6 \%), 13.24 \mathrm{~min}(16.7 \%)$, and $15.3 \mathrm{~min}(2.9 \%)$ (Fig. 3) Falasca et al. (2016) found that the most abundant monoterpene identified in $J$. communis fresh berries was $\alpha$-pinene (13.43-32.34\%), following sesquiterpenes, namely Germacrene D (12.29-20.65\%), $\beta$-Caryophyllene $(7.72-11.77 \%), \quad \gamma$ Cadinene $(3.86-5.47 \%), \alpha$-humulene $(5.21-7.87 \%)$, germacrene B (4.84-9.33 $\%$ ), and bicyclogermacrene $(2.50-4.18 \%)$. Orav et al. (2010) found that the 
main compounds in essential oil from J. communis were $\alpha$-pinene, germacrene D, (E)- $\beta$-caryophyllene, and $\beta$-myrcene.

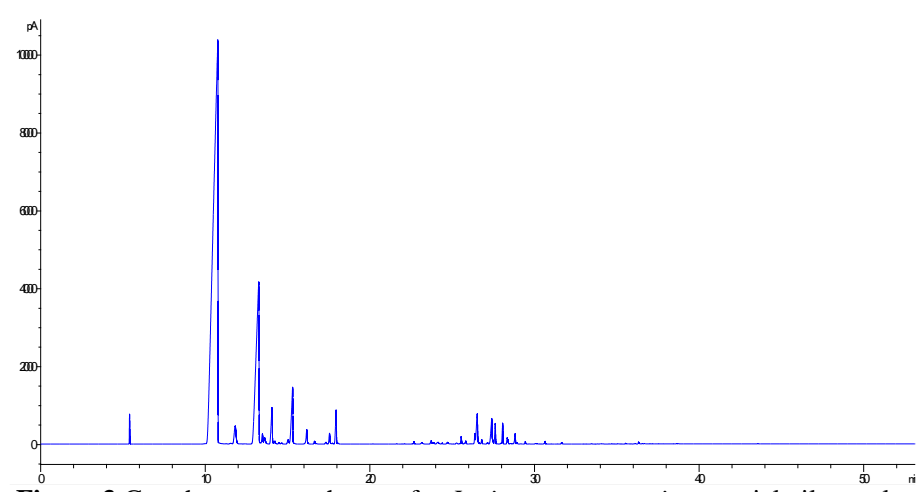

Figure 3 Gas chromatograph trace for Juniperus communis essential oil sample.

Essential oil isolated from E. globulus leafs showed the dominant peak at 17.95 $\min (81.7 \%)$ and some minor peaks at $15.5 \mathrm{~min}(7.3 \%)$ and $18.23 \mathrm{~min}(6.4 \%)$ (Fig. 4). Sacchetti et al. (2005) observed that the major compounds in essential oil from E. globulus were 1,8-cineole $(52.6 \%), \alpha$-pinene $(20.0 \%)$, and $\alpha$ Phellandrene $(6.2 \%)$.

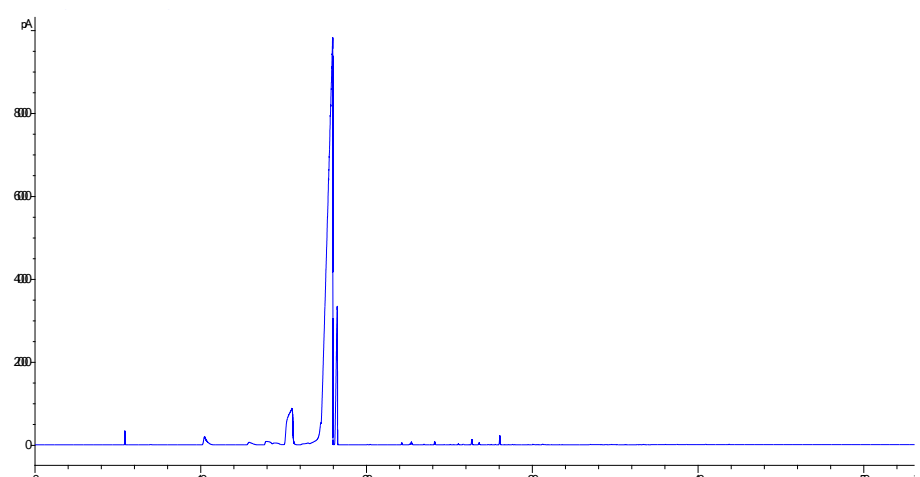

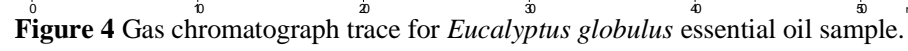

The last sample of essential oils was isolated from $C$. odorata flower. The gas chromatograph showed the dominant peaks at $24.38 \mathrm{~min}(22.98 \%), 43.92 \mathrm{~min}$ $(18.28 \%)$, and $30.42 \mathrm{~min}(7.7 \%)$. Minor peaks were registered at $27.49 \mathrm{~min}(4.6$ $\%$ ), $29.1 \mathrm{~min}(4.9 \%)$ and $32.79 \mathrm{~min}(3.4 \%$ ) (Fig. 5). Sacchetti et al. (2005) analyzed the chemical composition of essential oil from $C$. odorata and found that the most abundant compounds were benzyl benzoate $(33.61 \%)$, linalool $(24.5 \%)$, benzyl salicylate $(12.89 \%)$, benzyl acetate $(9.77 \%)$, and methyl salicylate $(2.79 \%)$. The main components of cananga oil were trans carryophyllene $(39.03 \%), \alpha$-humulene $(11.59 \%), \alpha$ - bergamotene $(11.29 \%)$ and germacrene (10.94\%) (Mahfud et al., 2017).

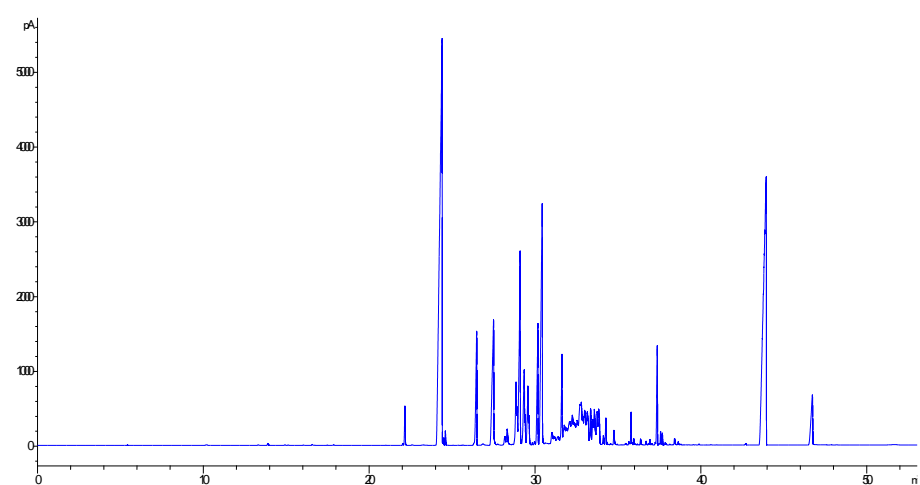

Figure 5 Gas chromatograph trace for Cananga odorata essential oil sample.
Misharina and Samusenko (2008) found that essential oils exhibit antioxidan activity that largely depends on their composition in their study on the antioxidant properties of essential oils from lemon, grapefruit, coriander, clove, and their mixtures. Furthermore, Misharina et al. (2011) found that the antioxidant activity of lemon peel essential oils depends on the system composition and concentrations of essential oils. Individual citral and limonene displayed the lowest antioxidant activity, whereas the activity of their mixture was higher, which explains the synergetic effects in the antioxidant activity of the components. The antioxidant activity of essential oils is revealed in Table 1 . In our study the best antioxidant activity varied from $0.997 \%$ of Juniperus communis to $73.137 \%$ of Cananga odorata. The essential oil of Citrus paradise showed $58.96 \%$ of antioxidant acitivty. $C$. grandis oils and cold-pressed $C$. paradisi oil displayed weak DPPH radicals scavenging capability. DPPH scavenging capacity of cold-pressed $C$. paradisi oil was less than $20 \%$ (Ou et al 2015). Distilled $C$. paradisi oil exhibited the potent DPPH scavenging capacity among 4 citrus oils; the $\mathrm{EC}_{50}$ value was more than $40 \mathrm{mg} / \mathrm{mL}$. This is consistent with previous studies where 34 kinds of $10 \mathrm{mg} / \mathrm{mL}$ citrus oils obtained from Japan and Korea and Italy exhibited weak DPPH radical scavenging effect ranging from $12 \%$ to $17.7 \%$. There are studies that reported antioxidant activity of galbuli EO from J. communis (Höferl et al., 2014) and J. excelsa (Emami et al., 2007). Our results showed very faint activity of $J$. communis. The DPPH scavenging activity was highest in E. citriodora $(82.1 \%)$, followed by $E$. camaldulensis $(81.9 \%)$ and E. microtheca $(81.8 \%)$ as compared to positive control BHT (Ghaffar et al., 2015). We found in our study E. globulus $31.63 \%$ of antioxidant activity. DPPH assay was used to evaluate the antioxidant property of $C$. odorata extracts to determine the free radical scavenging properties of the extracts. The ethyl acetate extract of the stem bark of $C$. odorata revelled to exhibit the maximum \% of DPPH inhibition (79\%) when compared to other investigations (Kusuma et al., 2014). Our results showed similar values of the antioxidant activity.

Table 1 Antioxidant activity of essential oils

\begin{tabular}{lc}
\hline Essential oil & Antioxidant activity \% \\
\hline Citrus reticulata & 3.40 \\
Citrus paradisi & 58.96 \\
Juniperus communis & 1.00 \\
Eucalyptus globulus & 31.63 \\
Cananga odorata & $\mathbf{7 3 . 1 4}$ \\
\hline
\end{tabular}

Table 2 summarizes the antimicrobial activity of the five EOs studied against 5 isolated Staphyloccus species isolated from human semen with MALDI TOF MS Biotyper. Citrus EOs are complex mixtures of different compounds and their antimicrobial activity depends on their chemical composition. Methicillinresistant $S$. aureus was found to be the most sensitive to the three Eos of Citrus sp. because its growth was affected (Boudries et al., 2017). Martinez et al. (2003) found that mandarin oil (Citrus reticulata Blanco) variety Dancy showed an antibacterial activity against $B$. subtilis, $S$. aureus and $L$. monocytogenes. Whereas Espina et al. (2011) found that the inhibition zones of mandarin EO against $S$. aureus, E. coli $\mathrm{O} 157: \mathrm{H} 7$ and $P$. aeruginosa were 18.8, $20.0(\mathrm{~mm})$ and no inhibition, respectively, which is almost in accordance with our results. In our study the most sensitive Staphylococcus was S. homins MK-39, resistant to tobramycin against Citrus reticulata. Twenty milligram per milliliter coldpressed $C$. paradisi oil and distilled $C$. grandis oil exhibited very strong inhibitory effects against $S$. aureus (Ou et al., 2015). The most sensitive staphylococci to $C$. paradisi were $S$. hominis $M K-38$ and $M K-39$ resistant to tobramycin. Zheliazkov et al. (2017) found a strong antimicrobial activity of $J$. communis EO against Staphylococcus aureus subsp. aureus. The strongest antimicrobial activity of J. communis essential oil was found against $S$. hominis $M K$-38. Salari et al. (2006) used Eucalyptus globulus leaf extract to evaluate their activity on 56 isolates of Staphylococcus aureus. The EOs extracted from all seven Eucalyptus spp. showed antibacterial activity against $S$. aureus. The bes antimicrobial activity of E. globulus in our study were found against $S$. aureus MK-24 and S. capiti MK-26 and MK-27. Recent work from Indonesia showed that the stem bark extracts of $C$. odorata exhibited a great antimicrobial property using the agar well disc diffusion assay (Kusuma et al., 2014). C. odorata showed the best antimicrobial activity against $S$. hominis MK-38 and MK-39. 
Table 2 Antimicrobial activity of essential oils in $\mathrm{mm}$

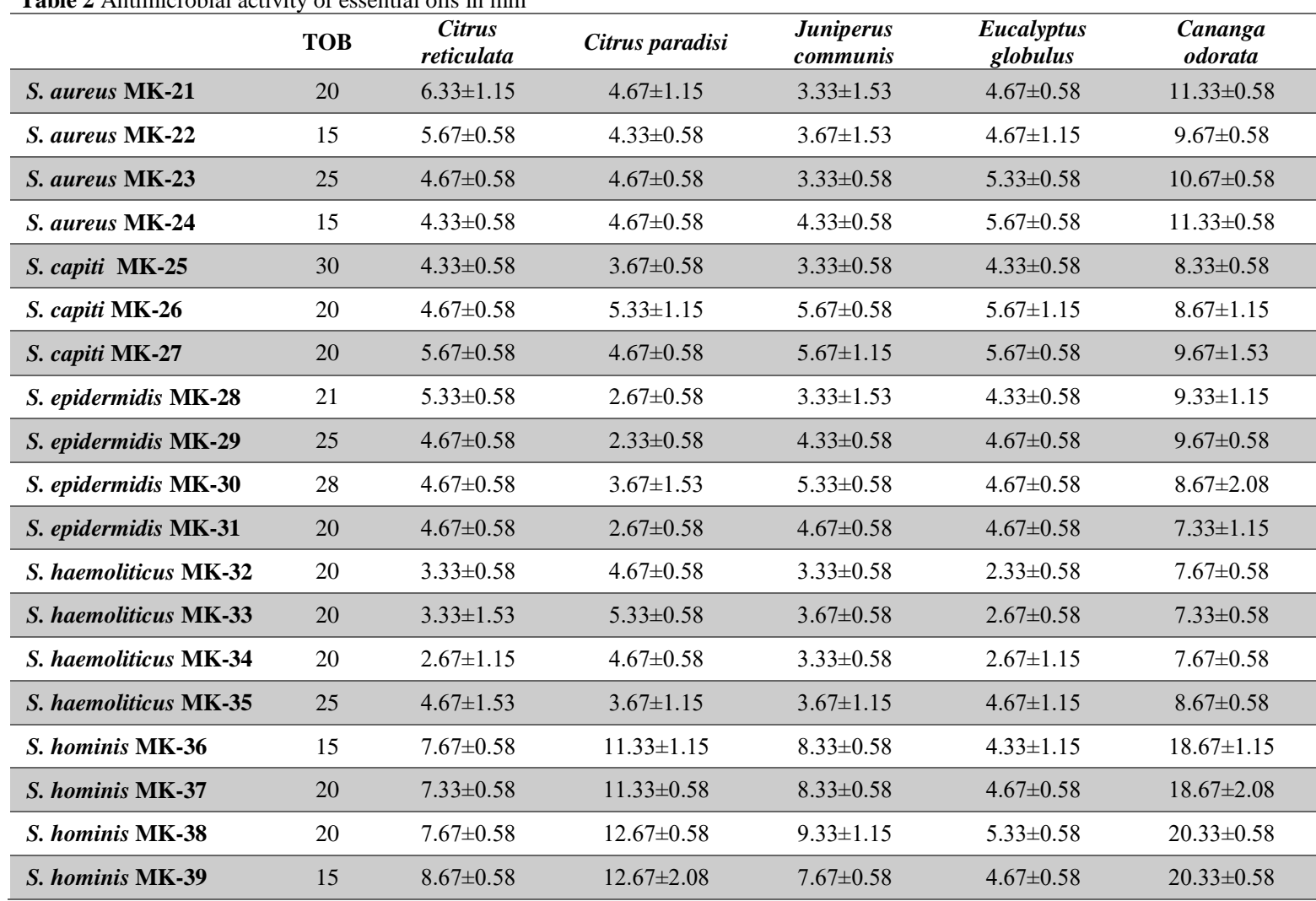

\section{CONCLUSION}

In view of their potential as inhibitors of pathogenic microbial growth as well as their antioxidant activity, the Citrus paradisi peel oil, Citrus reticulata peel oil, Juniperus communis fruit oil, Eucalyptus globulus leaf oil, and Cananga odorato flower essential oils may be recommended for formulation of plant based preservatives for enhancement of shelf life of food items by controlling their losses from bacterial contamination and lipid peroxidation during storage. Additionally, the abundance of Citrus paradisi peel and Citrus reticulata peel as by- products from food industry and Juniperus communis fruit, Eucalyptus globulus leaf, and Cananga odorata flower as renewable raw materials makes the use of essential oils obtained from these plant sources economically adventogenous for practical application, thus they can be considered as potential possible alternatives to synthetic preservatives.

Acknowledgments: This study was supported by the KEGA grant no. 009spu4/2018 and by the APVV grant no. APVV-15-0544

\section{REFERENCES}

BOUDRIES, H., LOUPASSAKI, S., LADJAL ETTOUMI, Y., SOUAGUI, S., BACHIR BEY, M., NABET, N., CHIKHOUNE, A., MADANI, K., CHIBANE, M. 2017. Chemical profile, antimicrobial and antioxidant activities of Citrus reticulata and Citrus clementina (L.) essential oils. International Food Research Journal, 24(4), 1782-1792.

CARPENTER, C.D., O'NEILL, T., PICOT, N., JOHNSON, J.A., ROBICHAUD, G.A., WEBSTER, D., GRAY, CH.A. 2012. Anti-mycobacterial natural products from the Canadin medicinal plant Juniperus communis, Journal of Ethnopharmacology, 143(2), 695-700. https://doi.org/10.1016/j.jep.2012.07.035 CRISTÓBAL-LUNA, CH. M., ÁLVAREZ-GONZÁLEZ, I., MADRIGALBUJAIDAR, E., CHAMORRO-CEVALLOS, G. 2018. Grapefruit and its biomedical, antigenotoxic and chemopreventive properties. Food and Chemical Toxicology, 112, 224-234. https://doi.org/10.1016/j.fct.2017.12.038

DAVID, M. Z., DAUM, R. S. 2010. Community-associated methicillin-resistant Staphylococcus aureus: Epidemiology and clinical consequences of an emerging epidemic. Clinical Microbiology Reviews, 23(3), 616-687. https://doi.org/10.1128/cmr.00081-09

DAVIES, J. 1994. Inactivation of antibiotics and the dissemination of resistance genes. Science, 264, 375-382.

ELAISSI, A., SALAH, K.H., MABROUK, S., LARBI, K.M., CHEMLI, R., HARZALLAH-SKHIRI, F., 2011. Antibacterial activity andchemical composition of 20 Eucalyptus species' essential oils. Food Chemistry, 129(4), 1427-1434. https://doi.org/10.1016/j.foodchem.2011.05.100

EMAMI, S.A., JAVADI, B., HASSANZADEH, M.K. 2007. Antioxidan Activity of the Essential Oils of Different Parts of Juniperus communis. subsp. hemisphaerica. and Juniperus oblonga., Pharmaceutical Biology, 45(10), 769776, https://doi.org/10.1080/13880200701585931

ESPINA, L., SOMOLINOS, M., LORÁN, S., CONCHELLO, P., GARCÍA, D., PAGÁN R. 2011. Chemical composition of commercial citrus fruit essential oils and evaluation of their antimicrobial activity acting alone or in combined

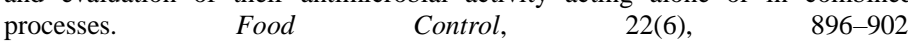
https://doi.org/10.1016/i.foodcont.2010.11.021

EUCAST, 2019. Clinical breakpoints and dosing of antibiotics. http://www.eucast.org/fileadmin/src/media/PDFs/EUCAST_files/

Breakpoint tables/v 9.0 Breakpoint Tables.pdf

FALASCA, A., CAPRARI, C., DE FELICE, V., FORTINI, P., SAVIANO, G., ZOLLO, F., IORIZZO, M., 2016. GC-MS analysis of the essential oils of Juniperus communis L. berries growing wild in the Molise region: Seasonal variability and in vitro antifungal activity. Biochemical Systematics and Ecology, 69, 166-175. https://doi.org/10.1016/j.bse.2016.07.026

FEINGOLD, B.J., SILBERGELD, E.K., CURRIERO, F.C., VAN CLEEF, B.A., HECK, M.E., KLUYTMANS, J.A. 2012. Livestock density as risk factor for livestock-associated methicillin-resistant Staphylococcus aureus, the Netherlands. Emerging Infectious Diseases, 18(11), 1841-1849. https://doi.org/10.3201/eid1811.111850

FOUDIL-CHERIF, Y., YASSAA, N. 2012. Enantiomeric and non-enantiomeric monoterpenes of Juniperus communis $L$ and Juniperrus oxycedrus needles and berries determined by HS-SPME and enantioselective GC/MS. Food Chemistry, 135(3), 1796-1800. https://doi.org/10.1016/j.foodchem.2012.06.073

GHAFFAR, A., YAMEEN, M., KIRAN, S., KAMAL, S., JALAL, F., MUNIR, B., SALEEM, S., RAFIQ, N., AHMAD, A., SABA, I., JABBAR, A. Chemical Composition andin-Vitro Evaluation of the Antimicrobial and Antioxidant Activities of Essential Oils Extracted from Seven Eucalyptus Species. Molecules, 20(11), 20487-20498. https://doi.org/10.3390/molecules201119706

GILLES, M., ZHAO, J., MIN, A., AGBOOLA, S., 2010. Chemical composition and antimicrobial properties of essential oils of three Australian Eucalyptus $\begin{array}{llll}\text { species. Food } & \text { Chemistry, 119(2), } & \text { 731-737. }\end{array}$ https://doi.org/10.1016/j.foodchem.2009.07.021

HÖFERL, M., STOILOVA, I., SCHMIDT, E., WANNER, J., JIROVETZ, L., TRIFONOVA, D., KRASTEV, L., KRASTANOV, A. 2014. Chemical composition and antioxidant properties of juniper berry (Juniperus communis L.) essential oil. Action of the essential oil on the antioxidant protection of Saccharomyces cerevisiae model organism. Antioxidants, 3, 81-98. https://doi.org/10.3390/antiox3010081

CHOI H.S., SONG H. S., UKEDA H., SAWAMURA, M. 2000. Radicalscavenging activities of citrus essential oils and their components: detection using 1,1-diphenyl-2-picrylhydrazyl. Journal of Agricultural and Food Chemistry, 48(9), 4156-4161. https://doi.org/10.1155/2015/804091 
KUSUMA, I. MURDIYANTO, W., ARUNG, E., SYAFRIZAL, T., KIM Y. 2014. Antimicrobial and antioxidant properties of medicinal plants used by the Bentian tribe from Indonesia, Food Science and Human Wellness, 3(3-4), 191 196. https://doi.org/10.1016/j.fshw.2014.12.004

LOTA, M.L., SERRA, D.R., TOMI, F., CASANOVA, J. 2001. Chemical variability of peel and leaf essential oils of 15 species of mandarins, Biochem. Syst. Ecol. 29(1), 77-104. https://doi.org/10.1016/s0305-1978(00)00029-6

MAHFUD, M., PUTRI, D.K.Y., DEWI, I.E.P., KUSUMA, H.S., 2017 Extraction of essential oil from cananga (Cananga odorata) using solvent-free microwave extraction: a preliminary study. Rasayan Journal of Chemistry, 10(1), 86-91. https://doi.org/10.7324/rjc.2017.1011562

MARTINEZ, J., SULBARAN DE FERRER, B., OJEDA DE RODRIGUEZ, G. FERRER, A. AND NAVA, R. 2003. Antibacterial activity of mandarin essential oil. Revista de la Facultad de Agronomía, 20: 502-512.

MISHARINA, T.A., SAMUSENKO, A. L. 2008. Antioxidant Properties of Essential Oils from Lemon, Grapefruit, Coriander, Clove, and Their Mixtures. Applied Biochemistry and Microbiology, 44(4), 438-442. https://doi.org/10.1134/s0003683808040182

MISHARINA, T.A., TERENINA, M.B., KRIKUNOVA, N.I., KALINICHENKO, M.A. 2011. The Influence of the Composition of Essential Lemon Oils on Their Antioxidant Properties and the Stability of the Components. Russian. Journal of Bioorganic Chemistry,. 37(7), 883-887. https://doi.org/10.1134/s1068162011070168

MONGA, M., ROBERTS, J.A. 1994. Sperm agglutination by bacteria: receptorspecific interactions. Journal of Andrology, 15, 151-156.

OKUNOWO, W.O., OYEDEJI, O., AFOLABI, L.O., MATANMI, E., 2013 Essential oil of grape fruit (Citrus paradisi) peels and its antimicrobial activities. American Journal of Plant Sciences. 2013, 4(7), 1-9. https://doi.org/10.4236/ajps.2013.47a2001

ORAV, A., KOEL, M., KAILAS, T., MÜÜRISEPP, M., 2010. Comparative analysis of the composition of essential oils and supercritical carbon dioxide extracts from the berries and needles of Estonian juniper (Juniperus communis L.). Procedia Chemistry, 2(1), 161-167. https://doi.org/10.1016/j.proche.2009.12.023

OU, M.C., LIU, Y.H., SUN, Y.W., CHAN, C.F. 2015. The Composition, Antioxidant and Antibacterial Activities of Cold-Pressed and Distilled Essentia Oils of_Citrus paradisi and Citrus grandis (L.) Osbeck. Complementary and Alternative Medicine, 1-9. https://doi.org/10.1155/2015/804091

PAPADOPOULOS, P., PAPADOPOULOS, T., ANGELIDIS, A.S. BOUKOUVALA, E., ZDRAGAS, A., PAPA, A., HADJICHRISTODOULOU, CH., SERGELIDIS, D. 2018. Prevalence of Staphylococcus aureus and of methicillin-resistant $S$. aureus (MRSA) along the production chain of dairy products in north-western Greece. Food Microbiology, 69,43-50. https://doi.org/10.1016/j.fm.2017.07.016

QIUCHUN, L., YANG, L.,, YUANYUE, T., CHUANG, M., HANNE, I. XINAN,, I.. 2019. Prevalence and characterization of Staphylococcus aureus and Staphylococcus argenteus in chicken from retail markets in China. Food Control, 96, 158-164. https://doi.org/10.1016/j.foodcont.2018.08.030

REEVE, D., ARTHUR, D. 2002. Riding the citrus trail: when is a mandarin a tangerine? Perfumer Flavorist 27, 20-22.

SACCHATTI, G., MAIETTI, S., MUZZOLI, M., SCAGLIANTI, M., MANFREDINI, S., RADICE, M., BRUNI, R., 2005. Comparative evaluation of 11 essential oils of different origin as functional antioxidants, antiradicals and antimicrobials in foods. Food Chemistry, 91(4),621-632. https://doi.org/10.1016/j.foodchem.2004.06.031

SALARI, M.H., AMINE, G., SHIRAZI, M.H., HAFEZI, R., MOHAMMADYPOUR, M. 2006. Antibacterial effects of Eucalyptus globulus leaf extract on pathogenic bacteria isolated from specimens of patients with respiratory tract disorders. Clinical Microbiology and Infection. 12(2), 194-196. https://doi.org/10.1111/j.1469-0691.2005.01284.x

SÁNCHÉS-MORENO, C., LARRAURI, A., SAURA-CALIXTO, F. A procedure to measure the antioxidant afficiency of polyphenols. Journal of Science and Food Agriculture, 1998, 76, 270-276.

SAWAMURA, M., TU, N.T.M., ONISHI, Y., OGAWA, E., CHOI, H.S., 2004 Characteristic odor components of Citrus reticulata Blanco (Ponkan) coldpressed oil. Bioscience, Biotechnology, and Biochemistry, 68(8), 1690-1667. https://doi.org/10.1271/bbb.68.1690

TAN, L.T.H., LEE, L. H., YIN, W.F. CHAN, CH. K., KADIR, H.A., CHAN, K.G., GOH, B.H. 2015, Traditional Uses, Phytochemistry, and Bioactivities of Cananga odorata (Ylang-Ylang). Complementary and Alternative Medicine, 2015, 1-30. https://doi.org/10.1155/2015/896314

TONG, S.Y., DAVIS, J.S., EICHENBERGER, E., HOLLAND, T.L., FOWLER, V.G., Jr. 2015. Staphylococcus aureus infections: Epidemiology, pathophysiology, clinical manifestations, and management. Clinica Microbiology Reviews, 28(3), 603-661. https://doi.org/10.1128/cmr.00134-14

UYSAL, B., SOZMEN, F., AKTAS, O., OKSAL, B.S., KOSE, E.O. 2011 Essential oil composition and antibacterial activity of the grapefruit (Citrus Paradisi. L) peel essential oils obtained by solvent-free microwave extraction: comparison with hydrodistillation. International Journal of Food Science and
Technology, 46(7), 1455 to 1461 . https://doi.org/10.1111/j.13652621.2011.02640.x

ZHELJAZKOV, V.D., SEMERDJIEVA, I.B., DINCHEVA, I., KACANIOVA, M., ASTATKIE, T., RADOUKOVA, T., SCHLEGEL, V. 2017. Antimicrobia and antioxidant activity of Juniper galbuli essential oil constituents eluted at different times. Industrial Crops and Products, 109, 529-537. https://doi.org/10.1016/j.indcrop.2017.08.057 